\title{
Acute kidney injury as a severe complication of diabetic ketoacidosis in children: a case report
}

\author{
Faisal Bukkar, Novina Andriana, RM Ryadi Fadil, Ahmedz Widiasta \\ From 7th APPES Biennial Scientific Meeting \\ Nusa Dua, Bali. 14-17 November 2012
}

\section{Background}

Diabetic Ketoacidoasis (DKA) is associated with significant morbidity and mortality and probably could be prevented by earlier diagnosis of diabetes mellitus (DM) and intervention. The level alertness of primary care doctors and knowledge on DM play a role to prevent severe complication of DKA.

\section{Objective}

To highlight the acute kidney injury as a severe complication of DKA in children.

\section{Methods}

We reported a diabetic ketoacidosis patient developing acute kidney injury at Hasan Sadikin General Hospital Bandung, Indonesia.

\section{Results}

A 12-year-old girl from a rural area was admitted to our pediatric emergency with decreased consciousness. We reviewed there was a history of polyuria, polydipsia and marked weight loss. When she arrived at hospital, she was very ill, comatose state, severe dehydration and typical Kussmaul breathing. Her heart rate was 140/min with thread pulse, low blood pressure, dry mucous membranes, sunken eyes, poor capillary return, and cold fingers. Laboratory analysis showed her blood glucose level was $890 \mathrm{mg} / \mathrm{dl}$, severe metabolic acidosis and urine ketones $3+$. The patient was resuscitated with iv fluid as soon as possible, followed by insulin and potassium chloride. On day 2 she developed oliguric and her serum creatinin and urea levels were 2.25 and $124 \mathrm{mg} / \mathrm{dl}$ that impressed as acute kidney injury. After fluid restriction she had persistent oliguric, increased serum creatinin and urea up to 7.34 and $234 \mathrm{mg} / \mathrm{dl}$ warranted initiation of

Department of Child Health, Faculty of Medicine, Universitas Padjadjaran, Dr. Hasan Sadikin General Hospital, Bandung, Indonesia peritoneal dialysis. After peritoneal dialysis and DKA management she showed a good improvement.

\section{Conclusion}

Patient with severe DKA developing acute kidney injury need early recognition and initiating renal intervention may improve the potentially poor outcome.

Published: 3 October 2013

doi:10.1186/1687-9856-2013-S1-P6

Cite this article as: Bukkar et al:: Acute kidney injury as a severe complication of diabetic ketoacidosis in children: a case report. International Journal of Pediatric Endocrinology 2013 2013(Suppl 1):P6.
Submit your next manuscript to BioMed Central and take full advantage of:

- Convenient online submission

- Thorough peer review

- No space constraints or color figure charges

- Immediate publication on acceptance

- Inclusion in PubMed, CAS, Scopus and Google Scholar

- Research which is freely available for redistribution
() Biomed Central
C Biomed Central

() 2013 Bukkar et al; licensee BioMed Central Ltd. This is an Open Access article distributed under the terms of the Creative Commons Attribution License (http://creativecommons.org/licenses/by/2.0), which permits unrestricted use, distribution, and reproduction in any medium, provided the original work is properly cited. 